\title{
CHAUCERIANA MINORA.
}

\section{Das dutum von Heinrichs IV. erstem Grant an Chaucer.}

Es gehört beinahe zum guten ton, über Godwin's Life of Chaucer zu lächeln, und das - allerdings in unkritischer weise aufgeschwollene - werk in die rumpelkammer zu verbannen. Eine genauere beschäftigung mit Sir Harris Nicolas jedoch könnte genügen, um zu zeigen, dass dieser gelehrte, der (bis Furnivall die reichlichen und höchst wertvollen nachräge zur Chaucer-biographie brachte) das beste Leben Chaucers schrieb, eigentlich Godwin als basis benutżte, und das falsche ausscheidend und viel neues hinzufügend, Godwin volle gerechtigkeit angedeihen liess. Derjenige teil von Godwin, der (bis ein vollständigeres werk kommt) seinen wert vollkommen behalten wird, ist die urkundensamlung im vierten bande, und aus dieser will ich hier eine urkunde hervorheben, die offenbar seit anfang dieses jahrhunderts nicht nachgeprüft, ja nicht einmal gelesen worden ist, und von welcher in getreulichem anschlusse an Nicolas ein falsches datum aus einem buch ins andre übergegangen ist.

Es schien mir immer eine merkwürdige "thatsache", dass Heinrich IV. im wahren sinne des wortes kaum auf dem throne warm geworden, sich des armen dichters erinnert haben sollte, dass dieser könig, ehe er noch an seinen eignen thronfolger den titel Prinz von Wales verliehen, und zu einer zeit, wo er nur wenige verleihungen und wichtigste staatsdokumente unterzeichnet hatte, 1 bereits an den alten - aber

1 vgl. Rymer etc.

Anglia N. F. IX. 
politisch völlig im hintergrund weilenden - freund seines hauses gedacht und bereits am 3. Okt. 1899 die schöne summe von 40 Mark jährlich dem früheren jahresgehalte hinzugefügt haben sollte.

Aber dies schien die thatsache zu sein nach Nicolas: The King accordingly doubled Chaucer's pension within four days after he came to the throne, by granting him, on the 3rd of October 1399, forty marks yearly, in addition to the annuity of $\mathscr{E} 20$ which King Richard had given him.' Als beleg dafür zitiert Nicolas (Aldine Ed. 1, 40): "Rot. Pat. 1. Hen. IV. p. 5, m. 12. G." G. bedeutet Godwin, und wenn wir Godwin aufschlagen $(4,302)$ finden wir als nr. 26 der urkundensammlung das dokument datiert: Teste Rege apud Westmonasterium, tercio decimo die Octobris. ${ }^{2}$ Per Breve de privato sigillo. Pat. 1. H. 4. p. 5, m. 12.

Dies giebt dem könige denn doch etwas mehr zeit!

Von Nicolas ging der $3.0 \mathrm{kt}$. in folgende werke über (und zweifelsohne in noch andere, die ich gar nicht nachgeschlagen habe):

1. Furnivall Trial Forewords p. 27:

1399, Oct. 3. Henry IV grants Chaucer 40 marks yearly in addition to his former $\mathscr{E} 20$ from Richard II.

2. Wards' Chaucer p. 75 :

the lines had the desired effect: for within four days after his accession, i. e., on Oct. $3^{d} 1399 \ldots$ Henry IV doubled Chaucer's pension \&c.

3. Hales in Dictionary of Nat. Biogr. $(10,166)$ :

[Chaucer] was not more satisfactorily placed till the accession of Henry IV, the son of his old patron the Duke of Lancaster (3 Oct. 1399). Four days after Henry came to the throne he granted Chaucer forty marks (26 l. $13 \mathrm{~s}$. $4 \mathrm{~d}$.) yearly, in addition to the annuity Richard II had given him \&c. (Nach Hales also kam Henry erst am 3. Okt. zur regierung und erhielt Ch. den grant am 7. Okt.!)

1 vgl. ib. p. 63: [Purse] a petition for that increase of his pension, which he obtained immediately afterwards.

2 An einem krönnugstage (Edw. Conf.) vgl. Rot. Parl. 3, 424. 
4. ten Brink, Hist. Engl. Lit. (Engl. Ausg. 2,1 p. 205):

On Sept. 30, 1399, Henry of Lancaster was chosen King .... Two days later Henry IV granted to the petitioner a yearly supplement of 40 marks to the $\mathscr{Z} 20$ salary given him by Richard. ten Brink rechnet also den 30. Sept. und den 3. Okt. nicht einmal mit!

5. Koch, Ausgewählte kleinere Dichtungen Chaucers p. XXI :

Und sein gedicht (Purse) fand schnell gehör. Am vierten tage nach seiner thronbesteigung, den 3. Okt. 1399 gewährte Heinrich IV \&c.

6. Jusserand Literary History of the English People 1, 342:

When Henry IV mounted the throne, within the four days that followed his accession, he doubled the pension of the poet (Oct. 3, 1399), who \&c.

7. Lounsbury Studies 1,90:

Four days after, on the $3^{\text {d }}$ of Oct. a grant of 40 marks \&c.

8. Skeat $\mathrm{Ch}$. Works $1, \mathrm{XLV}$ :

The King was prompt in reply (nämlich auf 'Purse') ... On Oct. 3, only the fourth day after the King's accession, the answer came \&c.

9. Ders.: Minor Poems p. 396:

Chaucer received his answer, in the shape of an additional grant of 40 marks, on Oct. 3 of the same year.

10. Ders.: The Student's Chaucer p.XII:

[Purse] in response to which, only four days afterwards [viz. "on Sep. 30 Henry IV became King of England], Henry granted ....

Andere werke haben sich oft allgemeiner gehalten und so den 3. Okt. vermieden; z. b. unter den älteren:

1. Speght (ed. 1602, b VI ${ }^{\text {verso }}$ ) zitiert in dem kapitel über die 'Rewardes' von Chaucer:

Anno primo Henrici quarti Galfrido Chaucero Armigero literae patentes confirmatae pro viginti libris nummorũ per annum durante vita \& vno dolio vini. 
Eodem etiam anno concessae adhuc \& datae eidem Galfrido Chaucero Quadraginta marcae per annum durante vita.

2. Urry (fol. 4) "in the same year he granted \&c.

3. Tyrwhitt (p. XII): In the next year \&c.

4. Hertzberg (p. 41): Erst als .... Heinrich den thron bestieg \&c.

Es ist merkwürdig, dass das richtige datum sich in einem werke findet, welches sicherlich nicht nachgeschlagen werden würde, ${ }^{1}$ wenn man ein genaues exaktes Chaucer-datum suchen würde, ein werk, dessen 4. auflage vom jahre 1896 mehr wie ein denkmal einer längst vergangenen zeit erscheint; ich meine Charles Cowden Clarke's Riches of Chaucer (p. 41):

Whether, however, he were a solicitor or not at the court of the usurper, that king in 18 days after his accession renewed to him all his former grants, and five days previously to this ratification, of his own free will, settled upon him an additional pension of forty marks per annum.

\section{Das datum von Heinrich's IV. zweitem 'grant' an Chaucer.}

a) Man liest in der Chaucer-Chronologie in Furnivall's Trial Forewards (p. 27):

Oct. 13. New Copies of his 2 grants of pensions are given to Chaucer, the old ones of 28 Feb. 1394 and 3. Oct. 1399 being lost.

b) Skeat (Chaucer's Complete Works 1, XLV):

Even then [im Okt. 1399] he met with a slight misfortune, in losing his letters patent; but having made oath in Chancery, that the letters patent of Feb. 28, 1394, and the new letters patent of Oct. 3, 1399, had been accidentally lost, he procured, on Oct. 13, exemplifications of these records (dazu wird kühl Godwin's Rot. Pat. 1 Hen. IV p. 1 . m. 18 zitiert, aber in wirklichkeit wurde nicht Godwin nachgeschlagen, sondern

1 Auch sei noch angeführt, dass Godwin 4, 149 die richtigen daten hat. 
Nicolas, der ja die arbeit so schön erleichterte, leider aber eine falle setzte!)

c) Lounsbury (Studies 1,90):

The records make known that copies of both these grants [1394 und 3. Okt. 1399] were lost soon after by Chaucer, and that in this same month he was furnished with new ones. Nothing can show more clearly how little it is we know of the real man that scholars [Lounsbury meint hier wohl Hales] have been reduced to see in the accidental disappearance of these documents a possible significance which may give some indication of his character.

Diese moralisation ist ja sehr angebracht, wenn sie nur Lounsbury bewogen hätte, die records selbst nachzuschlagen. Wir wissen meines erachtens gerade genug von Chaucer dem 'real man'.

d) Hales im Dict. Nat. Biogr. zieht bereits (wie Pollard später) moralische konsequenzen:

Perhaps it is worth noting as possibly significant of Chaucer's character that in a few days [d. $h$. zwischen dem 3. und dem 13. Okt. 1399!] he managed to lose his copy of this grant [nämlich vom angeblichen 3. Okt.!], and also his copy of the grant of 1394 . He was furnished with new copies on 13 Oct.

Unglücklicherweise ist diese behauptung einzig und allein "significant" für die art und weise, wie frühere bücher ausgeschlachtet werden und wie die (besonders für jeden, der in London arbeitet, leicht zugänglichen) quellen vermieden werden können.

Der irrtum geht wieder auf Nicolas zurück, welcher (Aldine Ed. 1, 40) sagt:

Having made oath in Chancery that the Letters Patent of the $28^{\text {th }}$ of February 1394, and $13^{\text {th }}$ of Oct. 1399 , before alluded to [Nicolas hat vorher nur vom 3. Okt. 1399 gesprochen und der 13. Okt. 1399 ist noch nicht von ihm erwähnt!] had been accidentally lost, he procured, on the $13^{\text {th }}$ of Oct. 1399 [das wäre also an demselben tage, an dem die zweite urkunde 
ausgestellt war!] exemplifications of those records. Als quelle führt Nicolas an Rot. Pat. 1 Henr. IV. p. 1. m. 18 G[odwin].

Godwin druckt die urkunde ab 4, 303, aber nicht ganz vollständig, er verweist, was den wortlaut der beiden verlorenen urkunden anbetrifft, auf seine Urkundensammlung nr. 23 und 25. Das betreffende dokument war bereits bei Rymer gedruckt, ist daselbst wie bei Godwin $0 \mathrm{ct}$. 18 datiert (nicht Oct. 131 wie bei Nicolas, Furnivall, Hales etc.), und enthält duplikate der urkunden, welche Richard II. ausstellte, datiert:

1. 28. Febr. "Anno Regni nostri Decimo Septimo."

2. 13. Oct. "Anno Regni nostri Vicesimo Secundo."

17 Richard II. ist 1394,

22 Richard II. ist 1398 (seine regierungsjahre laufen von Juni zu Juni; so dass 22 Richard II. von Juni 1398 bis Juni 1399, 23 Richard II. von Juni 1399 bis Sept. 301399 dauerte: bis zum tage seiner entthronung).

Dass Richard II. am 13. Okt. 1399 keine urkunde mehr ausstellte, hätte doch der gedanke an das datum von Heinrich's thronbesteigung klar machen können!

Schliesslich füge ich noch aus Rymer (Foedera \&c. ed. Hagae Comitis 17403 , 4, p. 165) das dokument an, von dem wohl niemand behaupten wird, dass es bereits genügend bekannt ist.

\section{Pro Galfrido Chaucer.}

Ann. D. Rex Omnibus, ad quos, \&c Salutem.

An. 1. Constat Nobis, per Inspectionem Rotulorum Cancellariae

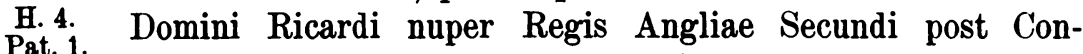
H. 4. p. 1 questum, quod idem nuper Rex Literas suas Patentes fieri m. 18. fecit in haec verba,

Ricardus, Dei gratia, Rex Angliae \& Franciae, \& Dominus Hiberniae, omnibus, ad quos praesentes Literae pervenerint, Salutem,

1 Wenn Issue Roll Easter 1 Hen. 4 (Nicolas 1, 107) den 21.0 ct. zitiert, so ist dies ein älteres versehen. Urry everso anm. $i$ hat das richtige datum! 
Sciatis quod, de Gratia nostra speciali, \& pro bono Servitio quod, dilectus Armiger noster, Galfridus Chaucer nobis impendit \& impendet in futurum, CONCESSIMUS eidem Galfrido Viginti Libras, percipiendas singulis annis ad Scaccarium nostrum, ad Terminos Paschae \& Sancti Michaelis, per æquales Portiones, ad Totam Vitam suam.

In cujus rei testimonium has Literas nostras fieri fecimus Patentes.

Teste meipso apud Westmonasterium Vicesimo octavo die Februarii, Anno Regni nostri Decimo Septimo.

Constat etiam Nobis, per Inspectionem Rotulorum ejusdem nuper Regis, quod idem nuper Rex alias Literas suas Patentes fieri fecit in haec verba,

RIcardus, Dei gratia, Rex Angliae \& Franciae, $\&$ Dominus Hiberniae, omnibus, ad quos praesentes Literae pervenerint, Salutem.

Sciatis quod, de Gratia nostra speciali, CONCESSIMUS, dilecto Armigero nostro, Galfrido Chaucer UNUM DOLIUM VINI PERCIPIENDUM singulis Annis, durante Vita sua, in Portu Civitatis Londoniae, per Manus Capitalis Pincernae nostri pro tempore existentis.

In cujus rei testimonium has Literas nostras fieri fecimus patentes.

Teste meipso apud Westmonasterium Tertio decimo die Octobris Anno Regni Vicesimo secundo.

Nos, pro eo quod idem Galfridus coram Nobis in Cancellaria nostra personaliter constitutus, Sacramentum praestitit corporale quod Literae praedictae casualiter sunt amissae, Tenorem Irrotulamenti earumdem Litterarum duximus Exemplificandum per praesentes.

In cujus, \&c.

Teste Rege apud Westmonasterium, xviij die Octobris.

[Peripsum regem.] ${ }^{1}$

1 Diese bemerkung ist noch hinzugefügt in Godwin 4, 303; Godwin weicht nur in der orthographie ab von Rymer; er hat: inspeccionem, cancellarie, inrotulamenti \&c. 


\section{Das datum von Chaucer's erster italienischer reise.}

Von der zähigkeit, mit welcher alte irrtümer in der Chaucer-biographie sich fortpflanzen, mag als weiteres beispiel angeführt werden, dass noch in Pollard's vielgepriesenem Globe Chaucer zu lesen steht (p. XVII):

For his expenses [nämlich während der italienischen reise] he was allowed an advance of a hundred marks, and a further sum of thirty-eight marks was paid after his return, which took place before Nov. 22 . 1373 , when he received his pension in person.

Nun hat Furnivall bereits 20. Dec. 1873 in den Further Additions and Corrections zu seinen Trial Forewords (p. 130), allerdings in zu kurzer form darauf hingewiesen, dass Chaucer's eigne rechnungen vom 1. Dec. 1372 bis zum 23. Mai 1373 laufen ["Chaucer's accounts for his journeys to Genoa and Florence, from 1. Dec. 1372 to 23. May 1373", Exchequer L. T. R. Foreign Accounts 47 Ed. 3, Roll 3]. Ferner hat Furnivall (1875. 1876) in einer note zu Thynne's Animadversions (p. 22) ausdrücklich konstatiert “Chaucer's embassy to Genoa and Florence was from 1. Dec. 1372 to 23. May 1373". Ich selbst habe ferner (zuerst auf hektographierten "daten" zu Chaucer Vorlesungen vom jahre 1890 und 1892), und später im Dial Feb. 16. 1895 bei gelegenheit einer besprechung von Skeat's grosser Chaucer-ausgabe geäussert:

“... when, under 1373, Dr. Skeat says of Chaucer's first visit to Italy, 'All that is known of this mission is that he visited Florence as well as Genoa, and that he returned before Nov. 22, 1373, on which day he received his pension in person', he does not lay sufficient stress on the fact brought to light by Dr. Furnivall in 1873, and mentioned by Skeat only in a note, that Chaucer's accounts of this journey run for the period between Dec. 1, 1372 to May 23, 1373. It would be strange indeed if these accounts had stopped in the midst of his journey. The more natural interpretation seems to be, that Chaucer's journey did not last more than six months; and so this document would corroborate what Professor Lounsbury expressed, for the first time I think, in 
the introduction to his edition of the 'Parliament of Foules' - that Chaucer had no time to learn Italian in Italy, but was sent there just because of his knowledge of the Italian language. Besides, the document seems to show that Chaucer returned months before the $22^{\text {i }}$ of November, there being no evidence that he stayed longer than May 23. The burden of proof, then, rests upon those who assume the later date."

Nun ist im vorigen jahre das dokument selbst veröffentlicht worden, dessen wortlaut keinen zweifel lässt, dass Chaucer's reise nur bis 23. Mai danerte - aber der Globe Chaucer wird wohl auch nach dieser notiz noch in spätern auflagen das datum angeben, welches seit 1873 hätte verschwinden müssen (das wir aber bei ten Brink, Hales, Lounsbury, Skeat etc. etc. getreulich angefïhrt finden).

\section{War Chaucer im jahre 1400 in Calais?}

Durch eine bemerkung des herausgebers der Chronique de la Traïson et Mort de Richart Deux Roy Dengleterre, 1 Benjamin Williams, wurde ich auf eine Chaucerurkunde hingewiesen, welche, soweit mir bekannt, für die Chaucerbiographie noch nicht ernstlich benutzt worden ist, obwohl B. Williams in jahre 1846 bereits die aufmerksamkeit auf sie gelenkt hat, und die frage aufwirft, die ich nach ihm von neuem aufwerfe, und die hoffentlich von einem historiker, welcher mit den lssue Rolls des Exchequer vertraut ist, beantwortet werden wird.

Williams spricht in seiner interessanten vorrede (p. XLIX) von der regierungszeit Richards II., und sagt u. a.: After such grievances from foreigners which were partly remedied by severe enactments in the $12^{\text {th }}$ and $19^{\text {th }}$ of Richard, Richard's alliance with France can not have been otherwise than displeasing to his people.

$\mathrm{Zu}$ diesem satze macht Williams die folgende anmerkung:

It has been stated by Mr. Godwin, that Chaucer, who had married Philippa, an elder sister of Cathe-

1 Herausgegeben für die English Historical Society 1846. 
rine Swynford, and had thus become identified with the Lancastrian party, had contributed in a considerable degree, in conjunction with John of Northampton, mayor of London in the early part of his reign, to excite the dissatisfaction of the Londoners, and that in consequence he fled to his father-in-law's (Sir Payne Roet's) house in Hainau. Although Sir Harris Nicolas has shewn, by diligently following Chaucer's course (Life and Poems of Chaucer ed. 1845, Vol. I.) that he could not have been thus absent from England, and that he was always in favour at court; yet a treasury order to him to receive ten pounds from the hands of the treasurer of Calais, 2 February 1400, (Pell Rolls, Michs. Term, 1 Hen. IV.,) appears a probable proof of his having been absent on the continent, and gives rise to some suspicion as to the cause.

Das von Nicolas zugänglich gemachte, aber in bezug auf die notiz betr. Calais nicht benutzte document (vgl. Aldine Ed. 1, 41; 106) lautet:

Issue Roll Mich. 1 Hen. IV, Die Sabbati xxjo die Februarii (1400).

Galfrido Chaucer cui dominus Ricardus nuper Rex Anglie secundus post conquestum viginti libras annuatim ad scaccarium ad totam vitam suam ad terminos sancti Michaelis et Pasche per equales portiones percipiendas per literas suas patentes concessit quas quidem literas dominus Rex nunc confirmavit una cum arreragiis super dictam annuitatem debitis usque in confirmationem earundem, In denariis per ipsum receptis de predicto Henrico (Somere) per manus Nicholai Usk thesaurarii Calesiae in persolutionem decem librarum sibi aretro existentium de hujusmodi certo suo videlicet pro termino sancti Michaelis ultimo preterito quas dominus Rex sibi liberari mandavit Habendas de dono suo per breve de privato sigillo inter mandata de hoc termino.

Das nächste (und letzte) dokument vom 8. Juni 1400 (bei Nicolas 107) fügt den namen des treasurer of Calais nicht bei, 
sondern liest einfach: . . . In denariis sibi liberatis per manus Henrici Somere in partem solutionis viij . li. xiii . s. v. d. sibi liberandarum de huiusmodi certo suo . . . . .

Wie kam nun der 'thesaurarius Calesiae' dazu, die betreffende summe an den dichter auszuhändigen? War der 'thesaurarius' vielleicht vorübergehend in London? War die summe sozusagen seinem 'ressort' überwiesen? (und warum?) Oder ist die einfachste auslegung der urkunde die, dass Chaucer im Februar 1400 in Calais war? 1 Ob auf einer geschäftsreise, oder gesandtschaft? Sind vielleicht mehrere der letzten Chaucerurkunden, welche zeigen, dass Chaucer seine pensionen nicht persönlich bezog, mit solchen abwesenheiten auf dem Continent zusammen zu bringen, und nicht als zeichen der absoluten altersschwäche $\mathrm{zu}$ nehmen?

Möge B. William's frage vom jahre 1846 bald beantwortet werden!

\section{Anmerkungen zum Globe Chaucer.}

Ich benutze die gelegenheit einer anmerkung, darauf hinzuweisen, dass Pollard's einleitung zum Globe Chaucer ten Brink's namen fein säuberlich umgeht (cf. XXII The generalisation which has been accepted of recent years \&c), dass solcher unsinn, wie Skeat's theorie über die abfassung der "unmoralischen" erzählungen der C. T. nach dem tode von Philippa Chaucer (1387) auch hier wiederholt wird, und zwar mit welchem pathos: p. XXI: we have some ground for believing that her death removed a moral influence which had previously made itself felt. Warum hat Pollard nicht lieber eine 'neue' theorie begründet, welche die unmoralischen erzählungen gerade dem einflusse von Chaucer's gattin zuschreibt? Woher wissen wir denn, dass diese nicht vielleicht eine 'lustige' geschichte gerade sogut goutirte wie das Wife of Bath? Wie kann man so ernst sprechen: we have some ground for be-

1 Kervyn de Lettenhove nimmt dies an, Froissart 20, 557 : Le 21 février 1400 Henri IV ordonne au trésorier de Calais de lui [= Chaucer] payer dix livres. On trouve dans les rôles des actes de Henri IV cette mention: diversa concessa Galfrido Chaucer. 
lieving! wo wir doch auch nicht den schatten eines 'grundes' haben.

Auch noch auf eine andere seite des Globe Chaucer möchte ich hinweisen, und das ist die ausgabe darin von den Minor Poems. Wir werden p. XXXII ernsthaft versichert: "the text here printed is the result of a careful collation and critical investigation of all the Mss printed in the Chaucer Society's publications, and of the Mss in the British Museum, in all cases where it was advisable or necessary to consult them." Eine bemerkung, die einem das wasser im munde zusammenlaufen macht, wenn man 6000 meilen vom Britischen Museum entfernt ist, und wenn man täglich dr. Furnivall's namen segnet für das enorme was er geleistet hat; denn was Chaucer's text anbetrifft, so sitzen wir alle an Furnivall's tisch!

Aber wie hat Mr. Heath nun "all the Mss printed in the Chaucer Society's publications" "sorgfältig" benutzt? Antwort: Indem er (wie vor ihm übrigens Skeat, dessen texte sehr mangelhaft und unvollständig gearbeitet sind, vgl. nur als kleine probe The Dial Feb. 16. 1895), was Furnivall in den Odd Texts und More Odd Texts veröffentlicht hat, ignoriert. Auf diese "sorgfältige" weise erhalten wir z. b.

bei Fortune von Heath (XLVII) die bemerkung "There are eight Mss", wo wir 9 haben [Heath's 8 + Ms. Arch. Selden B. 10];

bei Truth von Heath (XLVIII) die bemerkung: There are thirteen Mss [wo wir 17 Mss haben!];

bei Stedfastnesse: "There are eight Mss" [wo es 9 sind]; bei Scogan: "There are 3 Mss and one edition that of Thynne 1532" - wo wir seit den Odd Texts 1880 auch Caxton's Fragment haben;

bei Purse: "There are six Mss" - wo wir noch das alte Phillips Ms hinzuzufügen haben etc. etc.

$\mathrm{Zu}$ welchen resultaten in den "stammbäumen" diese gewissenhafte nichtbenutzung des gesamtmaterials führt (namentlich bei Truth), kann man sich natürlich denken und werde ich bei anderer gelegenheit zeigen. Ich möchte übrigens (ganz beiläufig) bezweifeln, ob stammbäume von Mss in eine 
Globe Edition gehören, von Mss, von denen der besitzer des Globe Chaucer nicht einmal das datum erfährt!

Wenn ferner Heath (XLVII) unter Truth - mit verschweigung von Shirley's überschrift (die des verlorenen Cotton Ms sei hier ausser spiel gelassen), mit der auch Skeat leichtsinnig umspringt, und die ten Brink zu so herrlichen worten begeistert - sagt: "This ballade [and "Gentilesse"], show Chaucer in his gravest mood and reveal the finely-tempered spirit which underlay his ironical and sometimes cynical humour", so möchte ich das für eine schändung des Chaucerschen namens erklären, die nicht scharf genug gerügt werden kann. Chaucer kann sehr bitter, sehr scharf, sehr sarkastisch sein - aber die behauptung, dass Chaucer hie und da cynisch war, ist das schlimmste moralische verdammungsurteil, welches über ihn ausgesprochen werden konnte; sie zeigt in trauriger weise, dass Chaucer immer noch nicht allgemein verstanden wird (wenigstens von seinen herausgebern), sie sollte für das erklärt werden was sie ist: eine unwahrheit.

\section{Andere Chaucerdaten im Dictionary of National Biography.}

Wir sind gewohnt zum DNB, als zur letzten autorität, unsere zuflucht $\mathrm{zu}$ nehmen, und daselbst, wenigstens was daten anbetrifft, sichere auskunft zu erwarten. Was die urkunden zu Chaucer's leben von 1373 und 1399 anbetrifft, so haben wir oben gesehen, wie es mit der sicheren auskunft steht; hier will ich noch aus Hales' artikel die merkwürdige auskunft über Caxton's Chaucerdrucke anführen:

As to the printed editions, we may mention that the "Canterbury Tales" were printed by Caxton in 1475 , and again from a better manuscript a few years later.

Diese sicherheit des datums 1475 ist ja sehr erfreulich, wo wir seit Blades an fragezeichen $\mathrm{zu}$ fast jedem Caxtondatum gewöhnt sind; aber ich finde auch bei Bradshaw keine korrektur von Blades, auch im DNB (Caxt.) finden wir (wiederholt aus Blades, und deshalb sicher!) Chaucer's C. T. folio 1st edition Westminster? 1478? [9]; 2nd edition Westminster? 1484 ? with woodcuts [vgl. mein Lesebuch 1,300$]$. 
Skeat [Ch. Works 1,28] datiert die erste ausgabe: about 1477-78, die zweite 'about 1483' - falls er Bradshaw's urteil folgte, würden wir seine modifikation des datums annehmen; aber er schweigt über Bradshaw. ${ }^{\prime}$

Eine andere bemerkung, höchst merkwürdiges licht auf moderne Chaucerkenntnisse werfend, ist in Sidney Lee's artikel über Scogan enthalten (DNB 51,1). Da lesen wir:

"Among the manuscripts at Corpus Christi College, Oxford, there is a brief collection of proverbs, in metre, headed 'Proverbium Scogani' (Ms 203, f. 22); the first line runs

Flee from the pres and dwell wyth sothfastness.

This is ascribed to Chaucer in Urry's edition of that poet's works, but is certainly by Henry Scogan.

Wie würde 'that poet' über ein derartiges 'certainly' lächeln! Aber, um ernst zu bleiben, welcher bodenlose leichtsinn gehört dazu, solche 'sichere' behauptungen aufzustellen!

' Skeat datiert Wynkyn de Worde's ausg. der C. T. 1498; Hales: 1495. Was ist hier das richtige?

Stanford University, Cal.

Ewald Flügel. 